\title{
The spirit underneath: development, race and moral economy in Central Mozambique
}

\author{
Inácio Dias de Andrade
}

${ }^{1}$ Universidade de São Paulo (USP), Departamento de Antropologia Social, São Paulo/SP, Brasil

\begin{abstract}
Since 2007, Tete, a province in central Mozambique, has been experiencing an economic boom. Multinational mining companies are exploring one of the world's largest - and virtually untouched - coal deposits. Led by Brazilian-based multinational Vale, the controversial billionaire investment plans caught the attention of international NGOs and cooperation agencies that flooded Tete province with development and democracybuilding projects. Meanwhile, the inhabitants of Tete are suspicious. People in Tete have encountered various exogenous populations since pre-colonial times and are extremely familiar with the methodology of development organizations. However, the current "developmental and democratic times" pose an intriguing question to them: can we develop? To clarify this existential question - that has deep spiritual and racial implications - the article discusses the nature of inter-ethnic political community in the Zambezi Valley, correlating it with the region's pre-colonial and colonial history.
\end{abstract}

Key words: Development; Witchcraft; Moral Economy; Democracy; Mozambique. 


\section{O espírito latente: \\ desenvolvimento, raça e economia moral no centro de Moçambique}

\section{Resumo}

Desde 2007, Tete, província central de Moçambique, passa por uma grande expansão econômica. Empresas multinacionais de mineração estão explorando um dos maiores - e praticamente intocados - depósitos de carvão do mundo. Liderados pela brasileira Vale, o bilionário e polêmico plano de investimento chamou a atenção de ONGs internacionais e agências de cooperação estrangeiras que inundaram a província de Tete com projetos democráticos e de desenvolvimento. Enquanto isso, os habitantes de Tete estão receosos. Habituados a lidar com diferentes populações exógenas desde os tempos pré-coloniais, os tetenses também estão extremamente familiarizados com a metodologia das organizações de desenvolvimento. No entanto, os atuais "tempos de desenvolvimento e democrático" colocam uma questão intrigante para eles: poderíamos nos desenvolver? Para esclarecer esta questão existencial local - que tem implicações espirituais e raciais mais profundas - o artigo pretende discutir a natureza da comunidade política inter-étnica do Vale do Zambeze, relacionando-a com a história pré-colonial e colonial da região.

Palavras-chave: Desenvolvimento; Feitiçaria; Economia Moral; Democracia; Moçambique. 


\title{
The spirit underneath: development, race and moral economy in Central Mozambique
}

\author{
Inácio Dias de Andrade
}

The purpose of this article is to analyze how development in Tete has triggered different understandings about modernization, race and politics. Since large mining companies began to arrive in Mozambique in 2007, Tete has become one of the most dynamic provinces in the country. With the beginning of coal prospecting in 2011, a considerable foreign white community settled in Moatize and Tete City, the provincial capital. Formed by engineers, miners, machine operators and administrative staff, the foreign white population of Tete lives in the mining companies' private condominiums and has little contact with the local population. ${ }^{1}$

However, despite the social isolation of the companies and their workers, the massive presence of multinationals has dramatically altered Tete's landscape. It is impossible to ignore the presence of the massive piles of coal that rival the age-old mountains on the horizon. It is also easy to perceive the sudden change in the coloration of the sky when one arrives in the province. The clean and transparent air of the surrounding region becomes ocher-colored as one approaches Tete. Similarly, when one reaches the provincial capital, the tranquility of neighboring small towns and villages - which were once typical of daily life in Tete - is quickly altered. Tete's streets are filled with cars, chapas ${ }^{2}$ and bicycles; informal merchants sell all sorts of goods on the sidewalks, and people from different regions and countries circulate downtown in the busy city. Many immigrants who came looking for a job in the foreign companies have given up and roam the streets searching for any kind of opportunity. Additionally, every person whom I spoke to could firmly point out the roots of these new turbulent times.

"It's development" said Celestino Nota, a young farmer from whom I rented a small room on the outskirts of Tete. "Before you could lie on the road for hours. No cars would pass, but nowadays ..." he said without finishing the phrase while pointing to the busy National Road o7 (NR-07) that links Tete City to the Moatize mines.

In this sense, even though Mozambicans and foreign workers don't share the same spaces, and despite the fact that the large majority of people in Tete cannot find a job in the mining companies, it is impossible not to notice the changes brought by "development times". This becomes even clearer when we compare the current period with the time of socialist rule, which was historically marked by food shortages, population flight, forced migration and civil war (BORGES COELHO, 1989; GEFFRAY, 1990, WEST, 2009). For representatives of FRELIMO (the Liberation Front of Mozambique), a former guerrilla movement and now the ruling party, the arrival of multinational companies is proof of Mozambique's entrance to a new world order of development, modernization, employment and circulation of consumer goods and money. As one elementary school teacher from Maputo gladly told me when he was digressing about the new mining economy: "Brazil is Mozambique thirty years from now".

\footnotetext{
1 The ethnographic data were taken from my PhD Thesis "Tem um espirito que vive dentro dessa pele": feitiçaria e desenvolvimento em Tete, Moçambique (Dias de Andrade, 2016). The research was financially supported by CNPq and FAPESP.

2 "Chapas" is the local term for minivans imported from Asia used for collective transportation all over Mozambique.
} 
However, for most of the inhabitants of Tete, ${ }^{3}$ there are not many reasons for optimism. The advent of the mining economy was marked by social conflicts, forced evictions and police violence, while promises of new jobs, money and Western products for everyone were successively frustrated. Furthermore, for my interlocutors, the large crowd of immigrants who were suddenly transformed into a mass of unemployed seems to indicate that the development promised holds different and hidden elements.

In fact, for many of my interlocutors, the failure of developmental promises is directly linked to an unseen spiritual realm that precludes the development of African black populations. In this sense, the article aims to demonstrate that the local idea of development, based on the local experience of African populations and their centuries of coexistence with Portuguese colonialism, is encoded by a rigid and hierarchical perception about race and spirituality and is expressed in the language of witchcraft. Hence, my objective is to unveil the nature of a local system of moral obligations that defined how development is understood and put into practice.

I arrived in Tete for the first time in 2012. I wanted to understand how Mozambicans perceived this new era of development and Tete was the perfect location to do so. Vale - a Brazilian-based multinational mining company and the biggest investor in the region - had just announced a new ten-year plan that included US\$ 10 billion in investments until 2022. ${ }^{4}$ Vale began extracting the material in 2011 after an initial investment of $\$$ 1.88 billion. To increase extractive capacity, in 2016, the company inaugurated the Moatize II Project. Following conclusion of the Nacala railway in 2017, the production forecast for 2019 exceeded 18 million tons of coal. When production reaches its peak - estimated at over 22 million tons per year - more than $70 \%$ of the material extracted should be metallurgical coal, highly valued in the international market. According to government and company evaluations, the area granted to Vale alone has 1.87 billion tons of coal.

Unfortunately, the company's plan also included the eviction of thousands of families that were living on mining sites. By 2009, Vale had already evicted 2 thousand families and transferred them to another location. However, the construction of the houses, the transfer of people and the payment of compensation for losses were fraught with problems. In addition to building a residential condominium about $4 \mathrm{okm}$ from the people's original locations (which prevented many people from continuing their business that depended on their proximity to the city), Vale delivered poorly built houses whose structures cracked just a year after construction. Finally, the displaced population accused Vale and the government of not fully compensating them for their losses and several state officials were accused of corruption and mismanagement. 5

Members and partisans of FRELIMO affirmed that the social impacts of mining were a necessary evil of the development path. In 2013, the $53^{\text {rd }}$ anniversary of the promotion of Tete's capital to the category of a city, FRELIMO's politicians and supporters sang various songs about how FRELIMO brought development to Tete and disapproved of anyone who criticized the "development times". Meanwhile, the development lexicon was often used to celebrate the crowded streets, the vitality of formal and informal markets in the cities and rural villages, the intense circulation of people and cars, and the intensification of social relations among both relatives and strangers.

3 I use "people in Tete", "Tete's inhabitants" or Tetenses to refer to the autochthonous people with whom I worked with. I choose these designations instead of using local ethnic identities such as: Nyungwes, Tongas, Nyanja and others. These ethnic classifications are often used in Tete where the Manyungwes are by far the largest group. The current ethnic designations were forged among people of different origins in their secular relations with Portuguese settlers. Additionally, the recent economic expansion brought other ethnic groups to Tete. In any case, my research didn't focus on one specific population, but on how secular racial relations produced a long-lasting reciprocity system in Tete. Therefore, for my interlocutors, being "black" or "African" meant being part of a broader social category that defined the material and symbolic conditions of their lives. For a better understanding of how local ethnic boundaries were constituted and flourished, see Dias de Andrade (2016).

4 By 2014, Vale S.A., the largest investor in the region, had invested about \$1.9 billion in Mozambique (Silva, 2014). Vale also announced a \$10 billion dollar investment plan for the region until 2022. Although this amount has not yet been fully disbursed, the company's plan includes projects for a thermoelectric power plant, money for the development of a large farming project along the Nacala railroad, and social compensations to displaced populations.

5 In 2012, the evicted people paralyzed the company's production to demand better housing, job opportunities, full payment of compensation for losses and others claims. After a brief negotiation with the government, the police violently suppressed the protest. Tensions between the company and local population remain. 
In fact, the first thing I noticed when I arrived in Tete was the heterogeneity of situations that "development" could describe. Although the concept of development is most often used by politicians, technicians and bureaucrats, the idea of development is not foreign to most inhabitants of Tete. To the contrary, in Tete, development is not a word restricted to macro-political analyses, media debates, academic texts or political promises. The concept of development is used throughout the province, and the most isolated peasants regularly talk about their lives in terms of the presence or absence of development. Development, as a local aid-worker once told me, is "the arrival of all the good things".

In this sense, in Mozambique - and especially in Tete, "development" and "democracy" have become key concepts for defining current times. After the end of the civil war in 1992, Tete's residents were told that things would change: new jobs, health, education and development would come after the end of the socialist government. To accelerate this process, various NGOs founded countless development and democratization projects across the province. ${ }^{6}$ But nearly all were failures whose promises were never met. Nevertheless, when the mining companies' dollars began to flow, it seemed that the long-waited development had finally arrived. For many foreign aid workers and politicians based in Maputo, Mozambique had finally left the colonial legacy behind and entered what they called a "virtuous cycle of development".

Tete did experience an economic boom and dramatic changes in the social landscape were obvious. However, the local perception of development operates with various symbolic references and during my fieldwork discussions about development and the unfulfilled promises of modernity, the issues of colonialism, interracial relations and the spiritual realm of witchcraft were also raised.

A massive institutional and international economic structure seems to be overwhelming Tete Province with investments, jobs, goods, and projects. However, despite the impressive amount of money, products, industries and development programs that arrived in Tete in recent years, and contrary to the expectations created with the end of the civil war in 1992 and the arrival of democracy in 1994, local perceptions about the development period are increasingly negative. In the following sections I argue that to understand current perceptions of development times it is necessary to examine centuries of colonialism that built local understandings of inter-racial relations that are expressed in controversial statements on race, spirituality and politics.

\title{
"There is a spirit that lives inside this skin": spiritual explanation for economic predicaments
}

\begin{abstract}
"I asked if there were blacks in her country and she laughed and laughed. Oh, Fortin, you ask such odd questions! I was surprised: if there were no blacks then who did all the heavy work? Whites, she said. Whites? She was lying, I thought. After all, how many laws are there in the universe? Could it be that misfortune wasn't distributed according to race?"

Mia Couto. "The Russian Princess" in: The Picador Book of African Stories, 2001, 216.
\end{abstract}

Much ink has already been spilled to define the object of the so-called anthropology of development. During the 199os, the specialized literature sought to apprehend development phenomenon through an institutional critique of its practices and denouncements of the ethnocentric origin of its concepts. Many authors examined how development discourse legitimizes political interventions and social engineering projects in areas of the globe considered inferior to the developed North. Based especially on the works of Ferguson (1990) and Escobar (1994), anthropologists of development came to conceive of international NGOs, government agencies and other cooperation organizations as integral parts of a global governmental system "a governamental system that marked the geographical space and discursive field of the so-called Third World.

6 For a more detailed description of the postwar period in Mozambique, see Hanlon (2008), Smart (2008); Pitcher (2002) and West (2009). For a better understanding of postwar consequences in Tete, see Dias de Andrade (2016). 
In this sense, focusing on the institutional complex created by the developmental discourse, anthropologists sought not only to disassemble the historical process by which certain countries were idealized as places for specialized intervention, but also to understand the practical effects of these widely disseminated policies.

Thus, in this perspective, the analysis of the developmental phenomenon should privilege the elucidation of its real purposes: to expand state bureaucratic power and depoliticize poverty, whose causes were reduced to technical issues, and to maintain the self-referenced network that the international aid system has implemented. ${ }^{7}$

However, in this article, I take a different conceptual approach to development. Although technical development networks and their methodologies and concepts are actively present in Tete, defining the ways in which money, projects and development benefits flow and create objects of specialized intervention, I argue that the perception about the development times in the Zambezi Valley is related to diversified and particularly local factors.

Based on the local experience of African populations and their centuries of coexistence with Portuguese colonialism, the local idea of development is encoded by a rigid and hierarchical perception about race and spirituality and is expressed in the language of witchcraft. In this sense, I am interested in unveiling the nature of a local system of moral obligations that defined the means in which development is understood and put into practice.

This idea came to me one afternoon when I was on my way to N'kondezi, a village about $130 \mathrm{~km}$ from Tete City. I was going to visit one of the communities assisted by the Integrated Program of Poverty Reduction through Rural Development. This is the name of a local NGO set up within the Salesian Mission of Moatize, funded by Jurgen Eine Welt, an Austrian Salesian organization, which receives money from the Austrian Development Agency. Portuguese Catholic priests, hired six Mozambican technicians, graduates from local universities, to run the NGO. The program consisted of a few weeks of workshops for selected villages on "modern rural techniques", followed by courses on democracy and cooperative organization. By the time that the peasants were organized in "democratic groups" - i.e., after one or two months, depending on the villagers' engagement - the PICPDR (the cacophonic Portuguese acronym for the program) would begin to deliver seeds, pesticides, fertilizer, cattle and water pumps to the cooperative's members.

The total length of the program in each region would vary. Initially, the NGO supports the selected village for three years, although an extension of two more periods of three years could be granted. In villages where the coordinators noticed considerable potential for improvement, the program would continue. Otherwise, the technicians could consider the village to be incapable of meeting the program expectations and the project would be terminated. According to the Austrian consultant who spent one week in Tete assessing the program, the most common reason for ending a specific project in a village was the inability of the assisted peasants to perceive the project objectives as their own and "grasp the development with their own hands".

However, as I said before, development in Tete is not an unfamiliar word or concept. The beneficiaries are well aware of how the development projects work. Any peasant who is assisted by international organizations knows, in one way or another, how they should elect their peers for the peasant associations, how the modern rural techniques work, what are the goals of each project and what they must do to ensure the program's continuity. Development is a hot topic nationwide and Tetenses are constantly comparing their lives with the lives of the white foreigners who visit the province.

\footnotetext{
7 Despite good ethnographies concerning daily practices that escape institutional controls and about forms of resistance and subversion of projects, much of the discussion about development continues to focus on the analysis of the "technical apparatus and systemic logic of cooperation organizations, regarding it as a global phenomenon" (Cesarino, 2014: 28). To a large extent, this is because some authors - many of them participants in the developmental apparatus - analyze local perspectives to incorporate them into the technical corpus of agencies. In my thesis (Dias de Andrade, 2016), I argued that, in Tete, the expansion of the technical network of development is due less to internal mechanisms of reproducibility than to the spiritual and racial conceptualization of development.
} 
Thereby, whenever I took a chapa, and my fellow travelers realized that they had a white Brazilian companion, the subject quickly turned to a discussion about how far Mozambique stands behind Brazil on an imaginary chart of development.

I was in my second period of fieldwork and after spending five months in Tete in the previous year I was preparing myself for six more months of research in rural zones of Tete province. Actually, I had become quite familiar with this kind of conversation and had created a mental routine to respond to the curiosity with which Mozambicans address any foreigner from "developed countries".

That time was no different and I spent most of the three hour trip explaining how Brazilians lived - what we eat, how we cultivate our food and what the major cities that they were familiar with from Brazilian TV shows were really like.

After a while, one of my traveling companions told me that the kind of development I had described would not be possible in Africa. I had been careful to point out that there was also poverty in Brazil and that life was not as luxurious as they saw on television, but no matter how hard I tried, the insistent remarks about Brazilians' high living standards continued.

Although, for Brazilian readers, the idea that Brazil is a "developed country" may seem to be a clear overstatement, as a matter of fact, at the time I was in Mozambique, the Brazilian economy was experiencing strong growth. Most of Brazil's public infra-structure is more efficient and organized than in Mozambique, which was afflicted by two long wars in the past fifty years. Nevertheless, I was very careful to emphasize that any Mozambican or black person could be as developed as a Brazilian or any other foreigner. It was only a question of education, social class, economic infrastructure and cultural background.

However, my interlocutors accepted none of my arguments. In fact, for my small audience, the reason for Mozambique's lack of development was different. Long after the discussion had calmed down, Francisco, a skinny little man seated by my side, told me quietly why Mozambique could never stand on the same level of development as Brazil.

"There is a spirit that lives inside this skin", he said showing his arm and emphasizing his color.

With that sentence, Francisco began to tell me his story. Sometime before, he was making a lot of money from his own SIM card resale business. He bought each SIM card for 10 meticais and resold them for 20 meticais - a profit of US $\$ 0.15$ cents. His customers were foreign mining workers and his life was beginning to improve. But one night two men entered his house, and when he woke up and caught the thieves, one of them struck him with an iron bar in the middle of his face, knocking him out.

"It ruined all my teeth" he said showing me his empty mouth.

"They took everything I had. That is why we cannot develop ourselves. No Mozambican can see someone else get a better life for himself. Black people are like that" he said.

"We are envious"

Looking tired, he leaned against the window and thought for a few seconds:

"There's a spirit in here", he sorrowfully concluded showing his arm and his color once again.

That was not the last time I heard a racial and spiritual explanation for economic predicaments. Zé Nova, a peasant from Mameme, another location served by the project, also tried to explain to me why black people could not take part in the modern world. As he looked at the cross of a church, he told me:

"Isn't Jesus white? Blacks and whites are the same, the blood inside our veins are the same" he said as he pointed at my arm, "but the skin and brain are different. God made us different, made the white smarter"

Felipe, a young man who like others was looking for a job in the many companies that have recently arrived in the region, summed up a common narrative in Tete, used constantly to explain the envious nature of blacks: 
"When God created the world, He called the three races to talk and asked what they wanted for themselves. The white man said that he wanted to have lots of ideas and God gave him the gift of intelligence. The Indians said they wanted to do business, so they have a bunch of stores now. God gave them the gift of trading. But when God called the black man, he was laughing and joking, God, angry at his games, sent him to Africa and cursed him and all his children."

In Tete, black people associate themselves with tradition, envy and bad luck. God has doomed the entire race to the heavy work of farms and to the occult powers of witchcraft. For my interlocutors, "living by tradition", as black people do, is the opposite of whites. The people I spoke with affirmed that white people usually work in an office, out of the sun and without the heavy efforts of rural life, and are surrounded by technology and comfort. This kind of life would only be accessible to a black person who would dare to cross the hidden line that separates the visible world from the invisible realm of witchcraft. ${ }^{10}$ In this sense, development - differently from what the NGOs' international methodology describes - is not the product of a path taken jointly by the international staff and the beneficiaries, or even something able to arise from within the rural communities. Actually, Mozambique's lack of development is a burden carried by people who are silently fighting battles against envy and witchcraft.

To understand the current "development and democracy times" in the Lower Zambezi, Tete province, I suggest that we have to situate the development and democratic practices within the historic experiences of these populations and the relations that they built with the "vindouros", the Portuguese word for "those that came from outside" or zobuera in the local language.

In this sense, I use witchcraft stories to provide a symbolic background through which discourses, opinions and practices about current times circulate. ${ }^{11}$ From this cultural perspective, people draw strategies to mitigate the primitive burden that they think they must carry. To understand the role that "envy" and "witchcraft" play in the political perceptions of Tete citizens and to unveil this belief in a supposed African incapacity to develop themselves, I think that it is essential to examine the historic relations between whites and blacks

8 Peter Fry (2000) described a very similar narrative in a Christian community in Chimoio, the capital of Manica Province. After discarding functionalist explanations - in which such accounts originate from the relationship between a local population weakened by the war and Catholic solidarity networks, in a way that disregards the existence of several local institutions that could meet this need, Fry argued that the combination of Protestant asceticism with local "revolted spirits" produced an endless spiritual warfare in the Zambezi Valley. According to Fry, in the midst of a scarcity economy (Foster, 1960), Christian ritualism offered interpretive elements to justify the inferior place of the black population. On one hand, the accusations of witchcraft would be an eternal reminder to individuals about the responsibilities they owe to the corporate kinship group; on the other hand, they state the impossibility of removing the bonds of tradition. However, this interpretation does not help to explain the spread of black people's self-deprecating image beyond Christian communities. Likewise, it is difficult to understand the exponential growth in the number of associations willing to receive development projects despite the strong disbelief that its members demonstrate about the effectiveness of their methodologies and the possibilities of progress on the African continent.

9 "Viver à maneira" in Portuguese.

10 West (2009), in his ethnography conducted in Northern Mozambique, also described how witchcraft is associated to envy and to lack of development and democracy. Likewise, one can find in classical anthropology similar accounts about the relationship between envy and occult powers. E.E. Evans-Pritchard (2005) mentioned how the Azande understand witchcraft to be hereditary and that biological disease is triggered by a psychic act incited by envy, hatred or greed. Although recent studies have abandoned the paradigm of order and social integration incorporated by structural-functionalist analyses, current works of prominent anthropologists have shown that witchcraft practices and beliefs continue to offer a fertile subject for the study of material and spiritual insecurities boosted by political and economic changes (Comaroff \& Comaroff, 1993, 1999; Austen, 1993; Geschiere, 1997; Ciekawy, 1998, Smith, 2008; West, 2009). In this new perspective, anthropologists have gradually focused on unveiling how morality and anti-social sentiments of a given community change over time, fostering analyses of local understandings of power, political relations and economic inequalities.

11 Extending Evans-Prichard's argument that witchcraft provides a social explanation for misfortune, recent works have referred to modernity as an expanding social world through which local conflicts have arisen. In the same way, several of these studies have argued that witchcraft is a local idiom that reorganizes meaning and provides ways of acting in a changing world (Comaroff \& Comaroff, 1993, 1999; Austen, 1993; Geschiere, 1997; Ciekawy, 1998, Smith, 2008; West, 2009). This approach addresses the classical division that Evans-Pritchard had anticipated between witchcraft beliefs and witch-finding practices that, according to him, must be understood in relation to one another. However, in this article, I want to point out the idea, already suggested by Rosalind Shaw (2002), that in Africa witchcraft ideas emerged alongside colonialism, and express, until today, memories of its fierce regime. In this sense, I choose to address accounts of witchcraft as part of the process of inscribing difference (Montero et al., 2011) that is inexorably intertwined with colonization. Examining witchcraft practices as essential phenomena through which autochthons and settlers have theorized about themselves and others, I argue that colonial encounters made witchcraft stories an inescapable way of thinking about modernity and development in Tete (Dias de Andrade, 2016). 
in the region. Furthermore, I argue that the inter-ethnic relations or the Zambezi "moral economics" - a discursive realm unavoidably linked to belief in witchcraft - is central to understand why people seem to despise democracy. Thus, to fully apprehend the origins of the popular idea that relates black people to envy, witchcraft and under-development, a brief excursion into the history of Portuguese colonialism is necessary.12

\section{"We wanted political, not economic, independence from the Portuguese": moral economies in Zambezi Valley}

"Historians are familiar with seeing African societies break up under the influence of prolonged contact with Europeans. On the Zambezi it was the European society which dissolved, while the African, which was made up initially of fragments of other tribal organizations and language groups, developed new institutions and a new type of organization which proved better able than almost any other African society to resist European imperialism."

Malyn Newitt. "The Portuguese on the Zambezi: An Historical Interpretation of the Prazo System"

In: The Journal of African History, (10), 1969, 67.

During the fieldwork, my interlocutors constantly reminded me about the impossibility of democracy in Mozambique.

"You, white people, can solve things democratically because you help each other", Zé Nova, coordinator of the peasant association of Mameme said to me. He was trying to explain why the group created to distribute cattle in the village had fallen apart after the Austrian project ended.

"We, black people are envious. We can't help each other. That's why we are so less developed".

In 2014, I spent about five months with Zé Nova visiting different villages around Mameme. We intended to investigate the rural development project implemented by PICPDR with Austrian Development Agency funding. Like so many others projects in Tete, the PICPDR program consisted in distributing inputs, seeds, equipment and animals to groups of peasants organized in associations that were expected to emulate civil society organizations from developed countries. Like most villages in Tete, the Mameme farmers plant corn during the rainy season - from November to March. Once harvested, the maize was ground and preserved as flour for the rest of the year. This stockpiled flour is used to make xima, a porridge prepared with water and maize flour that is the staple of family nutrition in Tete and Mozambique in general. Hence, to improve food security, international projects have developed particular methodologies to produce vegetables during the dry season. Using Western planting and production techniques NGOs sought to increase the variety and quantity of food available and stimulate the local economy, since the harvest surplus could be sold in local markets, increasing farmers' income. To do so, NGOs provide local peasant associations with water pumps, seeds and cattle that should be used as draft animals to plow the fields. Zé Nova was one of the leaders of the Mameme association and was in charge of the Animal Management Committee. In this position, he became responsible for distributing a pair of animals to some members of the association. After the distribution, Zé Nova, who visited the beneficiary families to inspect the evolution of the project, should also redistribute the offspring of the original cattle to people who had not yet been assisted. It was his job to register families, organize committee meetings, and make sure the animals were being treated well, given tick baths and other veterinary care.

12 As proposed by Foucault (1995) I try to escape the historiographic tendency of producing links between facts or reducing them to elements of an identifiable linear history. The intention is to problematize relations of power that produce realities, knowledge and ways of thinking and feeling the world. In this sense, I am not interested in the consecutive association of historical events, but in the process of forming a local epistemology through which African populations of Tete perceive the world and which was able to perpetuate local ways of life throughout the centuries 
However, similar to what happened in other localities assisted by the project, as soon the farmers received their cattle, they sold them. Many farmers preferred to sell the animals in Malawi. According to Zé Nova, Malawian traders would pay more that Mozambicans. For Andreas, the European consultant to the project, it would take considerable time and effort for Mozambican farmers to realize that they could prosper more easily if they worked together in associations, sell their surplus and maximize their profits, acquiring new water pumps, seeds and equipment. Nonetheless, for the foreign staff of the PICPDR program, once the peasant associations were ready to perform their role in organized civil society, democracy could prosper and function from the bottom up, supported by grass-roots based organizations. It is not a coincidence that along with workshops on modern rural techniques, the farmers assisted by the project were also obliged to attend classes about democracy and political participation in modern societies. For Hannes Velik, International Director of Jugend Eine Welt, it was just a matter of time for the assisted communities to grab development by their own hands. As evidence, he presented the growing number of associations and beneficiaries of the Salesian development program. As matter of fact, in Tete, the total number of peasant associations grew exponentially over the last decade or so. In 2015, the UPCT (Provincial Union of Tete Peasants), the biggest peasant movement in the region, registered 176 associations. ${ }^{13}$

However, Zé Nova was assertive:

"Black people cannot decide things democratically".

If people in Tete are quite suspicious about the possibilities of development and democracy in Mozambique, why do they insist on creating new associations and taking part in successive workshops about modern planting techniques and democratic values? For an anthropologist of development, this phenomenon could be explained by the ability of development institutions and their bureaucratic complexes to replicate desired project results. Nonetheless, I argue that by considering the historic formation of colonial society, the growing number of projects and associations can also be explained by the active participation of people located at the edge of this network.

In contrast to the democratic principle of equal rights and duties, the inhabitants of Lower Zambezi have their "traditional political system". ${ }^{14}$ Despite centuries of colonization, a lineage system of reciprocity and control continue to politically organize Tete province. Actually, Portuguese settlers had reinforced the traditional political structures as part of the colonial administrative system. The lineage system is based on a concentration and redistribution of goods, rights, weapons, political power and other benefits by a powerful leader to whom other chiefs pay a tax. Given the fragile economic, political and military structure of Portuguese colonialism, the only way that some sort of European civilization could prosper in the region was by reinforcing these kinds of political systems (Pélissier, 1994 Capela, 1995; Schwartz, 2009; Thornton, 2009; Newitt, 2012; Rodrigues, 2013) - or as Allen first affirmed, by "Africanizing its institutions" (Isaacman, 1972). ${ }^{15}$

13 Since each NGO and development agency encourage new associations, creating an institutional network of their own, it is possible that this number is highly underestimated.

14 The adjective "traditional" refers to a complex array of categories of practices that people in Tete use to describe their daily lives in opposition to the way that they believe that white people live.

15 The notion of “Africanization" was first used in 1972 by Allen Isaacman in his Mozambique: The Africanization of a European Institution: the Zambezi Prazos: 1750-1902. Based on the idea of cultural resistance to political and economic domination, Isaacman emphasizes the African origins of the social structure of the main trading ports and Portuguese cities in Central Mozambique, acknowledging the pivotal role of the Afro-Portuguese community - known locally as muzungos - and its acculturation process. Although the idea of Africanization can be related to an outdated anthropological discussion of acculturalization, I would like to maintain the central idea of Isaacman's argument that the building of Portuguese colonial society in the Zambezi Valley cannot be understood without analyzing the interlocking of two different types of societies. In this sense, the Afro-Portuguese society was based on a complex array of phenomena that allowed the integration of local and exogenous social structures - Catholicism, international trade, Portuguese colonial structures and African political systems - and the "disintegration" of metropolitan values - caused by drought and famine, small-scale settlement patterns with low levels of technology and banditry. For more information, see Landeg-White (http://landegwhite.com/category/essays/page/2/, last accessed: 19/11/2018) 
In this sense, by transforming themselves into mediators between local societies and the international trade network, Portuguese settlers - known as prazeros - took the place of the big African chiefs. ${ }^{16}$ Some Portuguese settlers married powerful African women and integrated themselves into African kinship systems. Other prazeros traded Indian fabrics, beads and necklaces for political and military support and eventually became ritually married with traditional African Chiefs. In this way, just as King Monomotapa did when he unified the Kingdom of Gaza in the XIV century, the Portuguese began to distribute Indian products, European weapons and political rights to the tribes and lineages that submitted to their power and ruled through the traditional political system. In that way, Portuguese settlers, most of them originally born in Portuguese India, became the chiefs of a large African Army that negotiated and conquered land and new subjects for the expansion of the Portuguese colony of Mozambique. The Portuguese dependents would expand their network of dependents to strengthen their reputation, military power, commercial gains and political influence in Mozambique and Portugal.

However, for many inhabitants of the Lower Zambezi, voluntary enslavement, which had previously been thought of as a form of vulnerability, became, considering the limits imposed on black people by colonial society, a chance to improve their lives. Slavery in the African colonies was nothing like slavery in the Americas. In Tete, several African villagers walked long distances to participate in the "corpo vendido" ritual, literally translated as the "sold body" ritual (Rodrigues, 2013). The ceremony consisted in a performance in which black vassals enact a kind of accident that breaks a personal belonging of a Portuguese chief. After the ritual, the African subject became the prazero's dependent and one of his slaves.

Although the enslavement process in the Zambezi could also be established by imposed forms of subjugation - like war or slavery raids - it was mostly instituted by voluntary submission, especially in times of food crises. ${ }^{17}$ In the 1800 's the "sold body" ritual was widely spread throughout the province and the slave population grew. Consequently, a series of slave rights were created to ensure the continuation of the enslavement process and their proper treatment. Transgressions of this code by slave owners sparked massive desertions and revolts throughout the slavery period. Many prazeros were killed after being accused of excessively punishing their servants, not taking good care of them or selling them to slave merchants. There was an important code of conduct that should be respected by the slave master and their dependents. In this sense, for many, the submission to a kind and just master was often preferable to a free life with no food or protection (Rodrigues, 2013).

Moreover, depending on the task performed within the colonial production system, an enslaved African individual could really improve his life and political position in African societies. To become a mussambaze - a local tradesman that went to isolated villages to sell and purchase goods for his master - could change someone's life. Although the mussambaze's mission was to find products, slaves and new business opportunities for his master, they were always looking out for and aware of any profit opportunity for themselves. Through accounting tricks that were hardly checked by the prazero, they often bought slaves for themselves and brought back individuals and products that were quickly redistributed into their kinship and political networks (Rodrigues, 2013). This allowed them to increase their local prestige while increasing the prazero army. Commercial caravans were a great opportunity for enrichment and social mobility.

\footnotetext{
16 The name prazero came from the Portuguese word prazo, which was used for a time-limited land concession granted by the Portuguese crown. To encourage Portuguese colonists to settle in the African hinterland, the Portuguese administration created a three-generation system of land grants with mandatory succession in the female line. This system was widely utilized from the sixteenth to the eighteenth centuries throughout the Zambezi Valley.

17 In earlier studies, the "sold body" ritual was considered a minor event in Mozambique. For Isaacman (1972), most slaves were conquered through physical coercion. However, based on new documents and researches, both Rodrigues (2011 and 2013) and Newitt (2012) agree that the practice of offering oneself as a slave to a white lord, rather than being the exception, was the rule in Zambezi colonial society.
} 
To recognize that some Africans used the colonial system to improve their living conditions is not to ignore that the colonial system was based on an extremely violent social structure. In fact, several populations that could not or did not want to take part in these Afro-Portuguese societies fled as far as they could from Portuguese rule. In many cases, running away did not prevent these populations from being captured by the prazeros' black army, who would sell them like slaves in the Americas.

In the first half of the twentieth century, after termination of the slave trade, gold mines were discovered in neighboring areas of South Africa and the Portuguese developmental state began to privatize lands and invest in Mozambique. The colony was conceived as a labor exporting nation and thousands of Portuguese were sent to administer the new economy in the biggest colonization enterprise of Mozambique. In this period, inaugurated by a new labor regime implemented in 1899, many Africans worked without any payment and were harshly punished if they did not comply. The new labor regulation required the indigenous population to work and established that "rebel" natives should be sent for "correctional work" periods. In this sense, the country's new infrastructure, built during late-colonial times, was erected by the unpaid forced labor of black people and those African individuals that were not sent to the construction sites were used as a workforce on the farms of private companies (Newitt, 2012).

Although in the late colonial period labor relations and the dynamics of colonial exploration had changed, this did not affect the hierarchical structure of moral obligations established by the previous occupation. In fact, the opposite was true. The arrival of white settlers, factories, mining industries and the opening of new trade routes brought more products and economic agents into the Tete political system.

In this sense, despite the considerable violence, the colonization process also created a mid-level African social stratum that increased its power locally by dangerously serving as intermediary between white settlers and relatively isolated populations.

By redistributing products and benefits obtained through their influence over Portuguese settlers, many Africans became highly prestigious in their villages. Until the XVIII century, many of these Africans formed new ethnic societies known as Tonga, a Bantu word that in some Mozambican languages means "slaves". According to some histories, the Manyungwes, the largest and most powerful ethnic group in Tete, shared a similar origin. The group was forged as an ethnically homogeneous people thanks to its relations with Portuguese settlers. In Zambezi, the colonization process created a moral economy in which access to white people became a privileged way to obtain and increase wealth and political power. ${ }^{18}$

18 In his historical study of the English crowd, EP Thompson referred to moral economy as a traditional perception based on norms and social obligations that organizes economic interests. In his own words: "my object of analysis was the mentalité, or, as I would prefer, the political culture, the expectations, traditions, and indeed, superstitions of the working population most frequently involved in actions in the market" (Thompson, 1993: 260). After publication of Thompson's seminal book, the concept of moral economy gained a life of its own and was used in very fruitful ways by various authors in different contexts (Scott, 1976; Tausig, [1980] 2010; Austen, 1993). However, if, on one hand, the idea of moral economies provides a tool to address moral codes of local societies and their relations with broad exogenous structures, on the other hand, it could also help to sustain colonial perceptions of autochthonous practices. As Austen (1993) pointed out, the central trope in various attempts to define moral economy has been the opposition between the profit-oriented modern individual and the community ruled by a "subsistence ethic" (Scott, 1976) and by the concept of a zero-sum universe (Foster, 1965). Nevertheless, what should be emphasized in all these different studies is the importance of the economy of values and social norms of a group at any given time. Alternatively, as Austen affirmed: "Nonetheless, the moral economy school has a good deal to teach those more seriously concerned with culture. Most obviously, it demands that attention should be paid to the condition of access to material resources that determine, with some degree of autonomy, the understanding of capitalism possible within any community. Furthermore, in the revised version it provides detailed, socially sensitive accounts of political and economic strategies that illuminates any discussion of ideology" (Austen, 1993: 94) 


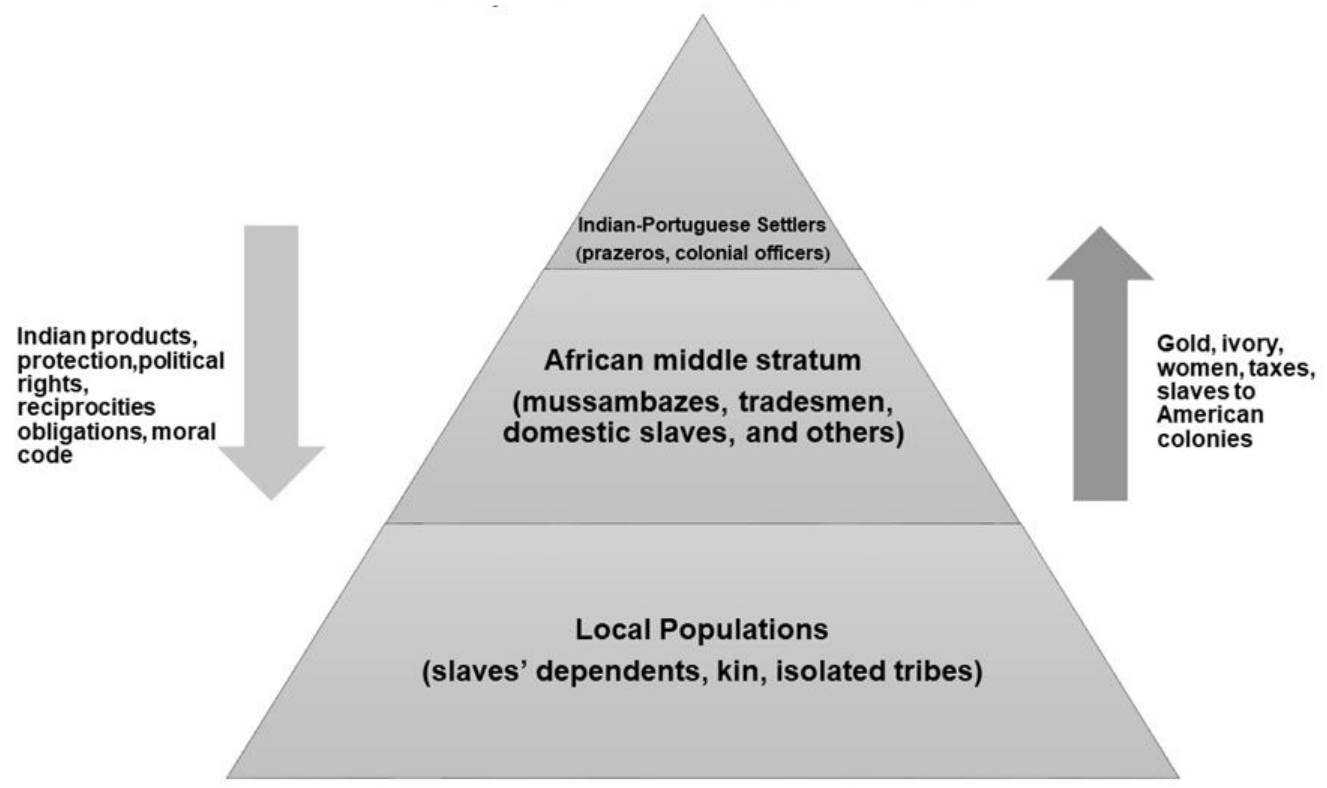

This helps explain why, until today, the fairness of a political system in Tete is indicated by the capacity of powerful individuals to redistribute goods and rights, while congregating in their surroundings a large network of dependents. To be seen as a merciful and just leader, Big Chiefs, white or black, should maintain these reciprocity chains of products, rights and benefits flowing. Otherwise they risk losing their men to better masters, facing revolts or even being killed. The same rule was applied to the dependents of white settlers, who were constantly reminded of their obligations towards their own villages.

In this manner, people in Tete tend to evaluate and identify different historic periods in terms of the activity within or rupture of this inter-racial reciprocity system. During late-colonial times, when Marcello Caetano, president of Portugal's Council of Ministers between 1968 and 1974, stated that the Zambezi Valley should be populated with one million white Europeans - at a time when the mining economy was mostly based on international consortiums and long-standing communities of white employees - the social structures of this moral economy were fully operating. At the time, driven by Portuguese state investment, Tete was experiencing unprecedented economic grow. Cabora-Bassa, the biggest dam in Southern Africa was under construction and lots of immigrants, money and products were flowing through Tete. When asked about the current development times, members of the generation who remember the late colonial period say it was more vibrant than today. As one old Mameme farmer said after returning from another failed job search at the region's mining companies:

"Today the Brazilians came to dig the mines, but we can't find any jobs. At least, in colonial times, the Portuguese gave some minor jobs to old men like me to earn a little change."

The presence of a white elite surround by a cheap black labor force created a hierarchical society built on the surplus of expendable dependents. In this way, many individuals who were not hired - or forced to work - in the old colonial coal mines were required to serve as domestic servants. Others seized the opportunities to sell local products to black people who had some sort of salary or tried to negotiate directly with foreign settlers.

This all changed when Samora Machel, FRELIMO's revolutionary hero, a liberation army general and the first president of the independent nation of Mozambique, took power. The combination of an unsuccessful agrarian reform that relocated many peasants to communal farms, controversial international policies during the Cold War, and a long-lasting civil war financed by surrounding apartheid regimes that 
gradually took on domestic traits helped to destroy the national economy and Tete's reciprocity network (Borges Coelho, 1989; Geffray, 199o; West, 2009). The desperate flight of Tete's white community that followed the rise of the socialist regime and preceded the outbreak of the Mozambican civil war also reinforced the idea that modernization and consumer goods were inextricably related to white men.

After the signing of the Peace Agreements in 1992 and the sudden arrival of development NGOs, people imagined that Tete's white community and the old local reciprocity network would be restored along with democracy. However, the end of the war overlapped with the professionalization and complexification of the socio-technical networks of development institutions (Mosse, Lewis, 2006). The increasing competitiveness of the international aid market led to a heated dispute over projects and beneficiaries throughout the Third World. The expansion of bureaucratic development structures became a way for large NGOs, agencies and international organizations to concentrate capital goods in the increasingly competitive globalized aid market (Vianna, 2014). In this sense, to compete in the market, international organizations promoted the creation of national and local NGOS that became valuable assets. The proliferation of local partners and the multiplication of social issues that were addressed by international organizations produced a variety of low-paid positions in the development network. Today, foreign aid workers are mostly based in Maputo, leaving field assignments to underpaid local employees.

Alexandre, a young man, who worked at the Tete Local Development Association (ADELT in its Portuguese initials) offered some interesting thoughts about the "development times" in Tete. The organization which he worked for was struggling to keep its doors open. ADELT had already managed some projects with the PICPDR on other occasions, but after the arrival of mining companies and the influx of new investments, the aid market in Tete became increasingly competitive. The international funding agencies began to require that projects, reports and assessment procedures be written in an indecipherable technical language that was easily understood by graduates of university development courses at European institutions, but completely obscure to Tete's NGO workers. The PICPDR managed to continue its projects with support from the Salesian philanthropic networks, but ADELT, founded by a Tete sociologist who sought to secure some of the investments that came along with the mining economy, was not so lucky. In commenting on the poor economic situation that the NGO finds itself, Alexandre compared current times with the hard but relatively prosperous life of colonial times:

"We wanted political independence from the Portuguese, but not economic independence. Eduardo Mondlane" [FRELIMO's first president who was killed by the Portuguese], "only wanted political independence, but Samora, when he gained power, sent all the Portuguese away"

There is no evidence that Mondlane really advocated any kind of long-term economic deal with the Portuguese after independence. However, in one of his first acts as President, Samora banished around 200 thousand Portuguese who were then living in Mozambique. Since the overwhelming majority of educated Mozambican personnel were white Portuguese, the measure not surprisingly interrupted all public services and infrastructure (Thomaz \& Nascimento, 2012). Samora's regime tried to mitigate the state paralysis by signing a long-term cooperation plan with European socialist republics, but the long civil war that took Mozambique by surprise prevented any economic improvement. In addition, the failure of the communal farming system and the rural production reorganization program helped create a food crisis that lasted for sixteen years (Thomaz, 2008 and West, 2009). All this prevented local African populations from maintaining their local political systems. 


\section{Democracy, development and envious spirits: local perceptions of political power}

Zé Nova was very disappointed with the last cattle breeders' association meeting. Once the Salesian NGO distributed livestock among the members, the association became powerless. No one would attend a meeting unless rumors of a new distribution arose. Moreover, the project's norms were completely ignored by the members. Disputes over the cattle's offspring were frequent and the progeny were often negotiated without the project's control, to attend local interests of each breeder. Zé Nova was exhausted after he scheduled several meetings that no one had interest in attending, but he knew exactly what was wrong:

"Democracy gave too much freedom to people. Today, people do whatever they please. When Samora was in power, people would never miss a meeting. They would come out of the bushes to hear him speak."

Ironically, the same associations that were celebrated by the foreign aid-workers as foundational pillars of Mozambican democratic society were seen by their members as sources of all kinds of problems. Actually, for my interlocutors, the expansion of the number of associations was perceived as a consequence of the erosion of political life and as proof of the incapacity of Mozambicans to deal with democracy.

"Black people don't help each other”, concluded Zé Nova, “That's why we can't have democracy. There is too much freedom these days."

During the visits to PICPDR projects in the villages around Mameme, Zé Nova and I spoke with assisted farmers in Inhangoma. Curiously, I had already met the president of the association in Inhagoma on a different occasion. The same peasant association was part of a very similar rural development project through a different institutional path. A few months earlier, I met presidents from several peasant associations that were being assisted by a Norwegian NGO's project, which was implemented by UPCT. The goals of the two projects were the same: to improve local food security by supporting vegetable cultivation with modern planting techniques and democratic organizations.

The methodology employed was also the same. On lands divided into 5x7 meter plots, different crops are planted with modern and traditional techniques. In the traditional method, seeds were planted without a standardized distance between them; the land was not fertilized and the plants were not treated for pests or disease. In contrast, the modern plot was cultivated with improved seeds, which received an organic fertilizer produced at the location with compost and animal manure. During sowing, the seeds were aligned, obeying a distance of $50 \mathrm{~cm}$ between beds. According to the foreign technicians, by comparing the results between the different methods, the farmers would realize the benefits of employing modern planting techniques and working collectively, replicating the techniques they learned in the association in their own crops. One hectare planted with the traditional technique produces from 8 ookg to 1.2 tons of corn, while the modern technique can produce over 6 tons in the same area.

In this scheme, the production of a surplus to be sold in the market is critical: with income from products from the association's collective farm, the peasants could afford more equipment for collective and individual use. In the same way, according to the Western technicians, introducing animal breeding and associative production was crucial to inducing a virtuous and endogenous cycle of sustainable growth, capable of creating the profit inflow needed to buy enhanced seeds, pesticides and fertilizers that would be used the next season. Initially, the improved seeds and other supplies were donated by the NGO. Afterwards, with some assistance from the NGOs, the peasants should be able to sow, grow, harvest and sell their products and earn enough money to buy new seeds, fertilizers and pesticides via the association. In this way, by helping peasants produce vegetables, the NGOs were simultaneously improving food security and introducing a new and valued product to local markets, since vegetables could be sold for more money than the traditional maize crops. 
However, none of this is new for Tete farmers. In the past quarter century various NGOs have come and gone from the region. Some of the farmers assisted by international organizations are familiar with the techniques used since their forced exile in Malawi during the civil war. In Inhagoma and Mameme, any member of the association could masterfully execute these techniques in the $35 \mathrm{~m}$ designated plots. In this small area, the farmers could weed the soil, carefully measure the distance between the beds and count every seed they buried. They also knew how to collect manure, mix it with grass and spread it on the ground. It was a simple and trivial task that they performed perfectly after years of experience with various NGOs and rural development programs.

However, the use of these techniques on individual farms was extremely exhausting. First, the amount of fertilizer needed far exceeded the capacity of the village families. A PICPDR technician calculated that each hectare planted needs $800 \mathrm{~kg}$ of fertilizer per season. Spreading it was heavy and stressful work and the majority of men and young people had moved to the city in search of work in the mining companies. Thus, farming was a task performed almost exclusively by older women. ${ }^{19}$

In fact, with rising prices due to the installation of mining companies, farmers across rural Tete have been forced to increase their acreage to be able to buy clothing, groceries and other commodities. In the past, cultivating two hectares was enough to support a family, but now many farmers must plant close to 7 hectares to earn the minimum needed. As Zé Nova told me, a goat, that used to cost about 250 meticais before the development outbreak, could be sold today for 1000 meticais - and could cost up to twice as much depending on the skin color or origin of those who buy it.

If that is correct, why did the number of peasant associations grow exponentially in recent years? Why were farmers throughout Tete forming new groups and actively searching for new projects? Sometimes, as the Inhangoma case shows, one peasant association could take part in more than two projects simultaneously. During my fieldwork, I witnessed several people from different rural zones of Tete coming and going in the PICPDR and UPCT's offices asking for new projects. When I was in N'kondezi I was often confused for a foreign NGO technician and approached by different people who "would like to be part of a development project".

Even though farmers are aware that the techniques taught offer better results, the international methodologies were largely ignored by them when they cultivated their individual fields. The extensive amount of work demanded by international projects and the inflation that obstructed real gains from selling vegetables made the members of the association produce specific crops just for show. Each farmer devoted just a few hours per week to the association farm where they applied the modern techniques under the supervision of local aid-workers, spending the rest of the time on their traditional maize crops. Some farmers have a small designated area on their land where they use what they have learned. In this portion of land they grow part of their family's food, using it as façade crop to show to directors and consultants from foreign NGOs - even though this is usually an unnecessary concern, since foreign NGO staff almost never extend their visit far beyond the grounds of the association's.

Actually, the growing number of peasant associations in the Tete region can be explained by the updating of old local strategies for inter-racial alliances. The peasant associations are assuming a role previously played by the marriage between prazeros and local women and the members of associations have become mediators between a "developed world" and local populations. However, differently from colonial times when the positions of mediators were authoritatively defined by prazeros and Portuguese officials and were more easily identified and controlled by their local network of dependents, today, to encourage democratic participation in Mozambique, NGOs and international development agencies stimulate the dissemination and autonomy of peasant associations. This movement created a growing competition among farmers who are continuously forming and disassembling peasant associations. As Zé Nova precisely summarized:

19 In fact, in Tete, as a general rule, male migratory work became a tradition reinforced by years of colonization and forced labor. In most of the villages, the farming is performed by women, but in current Tete, this an increasingly devastating job. 
In this sense, the associations developed ambiguous understandings of their function. For the members, the association is part of a strategic alliance between racialized counterparts through which goods, jobs and material gains are expected to flow. However, the goal of foreign technicians was to have the associations function autonomously and democratically with minimal outside interference or help. In this sense, the unmatched expectations on both sides produce frustrated technicians who are exhausted by constant demands from the farms' and association members who keep asking themselves where is the development promised by democracy.

Moreover, different from what Tete's inhabitants' first expected, the arrival of foreign investment did not bring jobs, money or consumer goods. The recent neoliberal agenda and technological improvements changed the mining production system. Differently from old colonial mining companies - implemented as part of a colonization plan for the region - the contemporary extractive industries employ far fewer people on their production lines and require fewer specialized foreign employees. ${ }^{20}$ To make things worse, since the end of the Socialist regime, people in Tete constantly ask where have all the white people gone to. Although Samora Machel is celebrated for ending the violent colonial regime, since the flight of Tete's white community, its inhabitants search for new ways to acquire Western products and new people with whom to form alliances.

When coal mining was initiated in 2011, the newly arrived white community joined the declining foreign white society in Tete Province. When the civil war ended, the international community reallocated a significant number of white aid-workers to Maputo, opening new underpaid local positions for native black employees and clearing the way for the ramification of their bureaucratic institutions. Moreover, the mining companies' employees in Tete live in fancy private condominiums near the mining site, and rarely interact with local people. The social distance also prevents the new white population from offering domestic jobs to the local population or from doing other kinds of business with them. ${ }^{21}$ In addition, the rising social inequality, the growing visibility of economic changes on the Tete landscape and the international communities insistence on failing methodologies led Tete's inhabitants to conclude that development is not something that black people can cultivate.

Consequently, many southern mashangana women from Tete are marrying newly arriving white men in Maputo, preventing the women from settling in Tete and revising the former inter-ethnic reciprocity system. From the Tetesenses' point of view, the absence of white foreigners and the subsequent lack of development is proof that mashangana - or top FRELIMO politicians - are monopolizing the means to access wealth and modern goods, transgressing the local moral economy. For them, this reinforces the ideas that black people are envious by nature and that democracy imposed a system of rules that no one obeys - which is a dangerous way to live in a land full of envious spirits. From this perspective, democracy is to be blamed for this recent disorder. By giving people "too much freedom”, democracy released the Africans' envious tendencies.

20 According to Ferguson (1999), the current neoliberal investment model of large multinationals favors strategic investments in high technology poles that demand skilled, mostly foreign workers with higher education. For Ferguson, mining projects in Africa are industrial enclaves closely integrated with the headquarters of multinational corporations and metropolitan centers overseas, but abruptly isolated from their own national societies.

21 The white employees of Vale were mostly young recently graduated Brazilians who accepted work in Mozambique to make more money than they would be able to earn in similar positions in Brazil. Senior Brazilian engineers rarely accept to go to Mozambique without asking for much more money than the company would be willing to pay. In the first phase of Vale's investment plan, the majority of Brazilians that came to Tete were single white engineers who lived in rental apartments downtown in the city of Tete or in large houses in Moatize - a village zokm from Tete's capital where the mines are located. They don't stay long and were hired to work in specific projects, returning to Brazil upon completion. They were responsible for the construction of the necessary facilities for the mining activities and were contracted to build the houses and other facilities that would receive the second wave of foreign workers. When coal extraction actually began, most Brazilian workers who arrived in Tete brought their families. They usually signed long term contracts and saw the job in Tete as a stepping-stone to a future position in Brazil. Since all the facilities were already built, the workers and their relatives lived inside the mining compound, in large blocks of houses surrounded by supermarkets, bars, sports courts, gyms and others amenities. 
After repeated corruption scandals and without any sign of development, in 2013, the former guerrilla and leader of the civil war army RENAMO (the Mozambican National Resistance), Afonso Dhlakama threatened to return to arms. Before his death in 2018, several villages in rural areas were attacked. FRELIMO troops were also ambushed on different occasions and some mining companies' had their logistical infra-structure sabotaged.

For most people in Tete democracy has failed to provide a sustainable political order, putting the national political community at risk. For Harry West (2009: 3), one of the most important tasks for anthropology in recent years has been the comparative study of neoliberalism and the political cosmologies that find continued expression in this global form of governmentality. He affirms that translating democratic rules into local idioms of power would provide new ways to give voice and power to those affected by poverty and exclusion.

However, my interlocutors affirm that the democratic principle of egalitarian power is precisely the cause of their predicaments. Therefore, I argue that engaging new forms of representation in a neoliberal globalized world necessarily involves the dismantling of democracy's discursive monopoly about good governance. This discourse allowed Western countries to impose their political perceptions on non-Western groups. Recognizing that local societies have their own ideas about political order - and not necessarily democratic ones - and revealing how these ideas developed over centuries of colonialism, socialism and democracy - is the first step to understanding these societies as legitimate political communities.

Meanwhile, feeling lost in this fight between two powerful political groups and without any other leader to turn to, Tete's population feels increasingly helpless. Picturing themselves as a powerless people on the brink of a new civil war, the residents of the Zambezi Valley constantly repeat an old saying that seems to summarize their predicament:

"When two lions fight, the grass suffers"

Received on: November 25, 2018

Approved on: July 03, 2019

Revised by: Jeffrey Hoff

\section{Bibliography}

AUSTEN, R.A. 1993. “The Moral Economy of Witchcraft: An Essay in Comparative History”. In: J. Comaroff and J. Comaroff (orgs.), Modernity and its Malcontents. Chicago: University of Chicago Press. pp. 89-110. BORGES COELHO, J. P. 1989. O inicio da luta armada em Tete, 1968-1969: a primeira fase da guerra e a reacção colonial . Maputo: Arquivo Histórico de Moçambique.

CAPELA, José. 1995. Donas, senhores e escravos. Porto: Edições Afrontamento.

CESARINO, Letícia. 2014. "Antropologia multissituada e a questão da escala: reflexões com base no estudo da cooperação sul-sul brasileira”. Horizontes Antropológicos, 20(41): 19-50.

CIEKAWY, Diane. 1998. "Witchcraft in Statecraft: Five Technologies of Power in Colonial and Postcolonial Coastal Kenya”. African Studies Review, (41)3: 119-141.

COMAROFF, J. and COMAROFF, J. 1993. Modernity and Its Malcontents: Ritual and Power in Postcolonial Africa. Chicago: University of Chicago Press.

. 1999. "Occult Economies and the Violence of Abstraction: Notes from the South African Postcolony". American Ethnologist, 26(2): 279-303. 
COUTO, Mia. 2001. "The Russian Princess”. In: Stephen Gray (org.), The Picador Book of African Stories.

London: Picador. pp. 213-223.

DIAS DE ANDRADE, Inácio. 2016. “Tem um espírito que vive dentro dessa pele”: feitiçaria e desenvolvimento em Tete, Moçambique. PhD Thesis, Instituto de Filosofia e Ciências Humanas, Unicamp - Campinas.

ESCOBAR, Arturo. 1994. Encountering Development: The Making and Unmaking of the Third World. New Jersey: Princeton University Press.

FERGUSON, James. 1990. The Anti-Politics Machine: "Development”, Depoliticization, and

Bureaucratic Power in Lesotho. Cambridge: Cambridge University Press. . 1999. Expectations of Modernity on the Copperbelt. Berkeley: University of California Press.

FOSTER, G. M. 1965. "Peasant Society and the Image of Limited Good”. American Anthropologist, 67: 293-315

FOUCAULT, Michel. 1995. As palavras e as coisas: Uma arqueologia das ciências humanas. São Paulo:

Martins Fontes.

FRY, Peter. 200o. “O Espírito Santo contra o feitiço e os espíritos revoltados: 'civilização' e 'tradição' em Moçambique”. Mana, 6(2): 65-95.

GEFFRAY, Christian. 199o. A Causa das armas: Antropologia da guerra contemporânea em Moçambique. Porto: Edições Afrontamento.

GESCHIERE, Peter. 1997. The Modernity of Witchcraft: Politics and the Occult in Postcolonial Africa.

Charlottesville: University of Virginia Press.

HANLON, Joseph; SMART, Teresa. 2008. Há mais bicicletas - mas há desenvolvimento?. Maputo: CIEDIMA.

ISAACMAN, Allen. 1972. Mozambique: the Africanization of a European institution: the Zambesi prazos, 1750-1902. Michigan: MPublishing University of Michigan.

MONTERO, Paula et al. 2011. "Para uma Antropologia do Político". In: Adrian Gurza Lavalle (org.), O Horizonte da política - Agendas de pesquisa e questões emergentes. São Paulo: UNESP. pp. 145-184.

MOSSE, David; LEWIS, David. 2006. Development Brokers and Translators: The Ethnography of Aid and Agencies.

Bloomfield, Connecticut: Kumarian Press Inc.

NEWITT, Malyn. 2012. História de Moçambique. Lousã: Publicações Europa-América LTDA. . 1969. "The Portuguese on the Zambezi: An Historical Interpretation of the Prazo System".

The Journal of African History, 10(1): 67-85.

PÉLISSIER, R. 1994. História de Moçambique - Formação e Oposição 1854-1918. Lisboa: Editorial Estampa.

PITCHER, Anne. 2002. Transforming Mozambique: The Politics of Privatization 1975-200o. Cambridge:

Cambridge University Press.

RODRIGUES, Eugênia. 2011. "Os cafres da religião: escravatura, trabalho e resistência”. In:

África: brasileiros e portugueses - séculos XVI-XIX. Rio de Janeiro: Mauad X. pp. 147-174.

. 2013. Portugueses e africanos nos Rios de Sena, os prazos da coroa nos séculos XVII e XVIII. Lisboa:

Imprensa Nacional-Casa da Moeda.

SCHWARTZ, S. B. 2009. "A Economia do Império Português". In: Diogo Curto; Francisco Bethencourt

(orgs.), A expansão marítima portuguesa, 1400-180o. Lisboa: Edições 70. pp. 21-51.

SCOTT, J. 1976. The Moral Economy of the Peasant. New Haven and London: Yale University Press.

SILVA, Marta Zorzal. 2014. "Cooperação Sul-Sul, Investimentos Externos e Desenvolvimento: Existem novas perspectivas a partir do sul global”. Cadernos de Estudos Africanos, 27(1): 33-54.

SHAW, Rosalind. 2002. Memories of the Slave Trade: Ritual and the Historical Imagination in Sierra Leone.

Chicago and London: The University of Chicago Press.

SMITH, James. 2008. Bewitching Development: Witchcraft and the Reivention of Development in Neoliberal Kenya.

Chicago and London: University of Chicago Press. 
TAUSSIG, Michael. 2010 [1980]. O Diabo e o fetichismo da mercadoria na América do Sul. São Paulo: Editora da Unesp.

THOMAZ, Omar Ribeiro. 2008. "Escravos sem dono: a experiência social dos campos de trabalho em Moçambique no período socialista". Revista de Antropologia, 51(1): 12-34.

THOMAZ, Omar R.; NASCIMENTO, Sebastião. 2012. "Nem Rodésia, Nem Congo: Moçambique e os dias do fim das comunidades de origem europeia e asiática”. In: Omar R. Thomaz et al. (orgs.), Os outros da colonização: ensaios sobre o colonialismo tardio em Moçambique. Lisboa: Imprensa de Ciências Sociais.

pp. 315-340.

THOMPSON, E. P. 1993. Customs in Common: Studies in Traditional Popular Culture. New York: New Press.

THORNTON, John K. 2009. “Os portugueses em África”. In: Diogo Curto; Francisco Bethencourt (orgs.), A expansão marítima portuguesa, 1400-180o. Lisboa: Edições 70. pp. 145-168

VIANNA, Anna Catarina M. 2014. Os Enleios da Tarrafa: Etnografia de uma relação transnacional entre ONGs. São Carlos: Ed. da Ufscar.

WEST, Harry. 2009. Kupilikula: o poder e o invisível em Mueda, Moçambique. Lisboa: Imprensa de Ciências Sociais.

Inácio Dias de Andrade

Postdoctoral Fellow at the Department of Social Anthropology, University of São Paulo (USP) https://orcid.org/oooo-0002-0156-8672

Author's Email: inacio.and@gmail.com 